\title{
Consumer's Buying Decision-Making Process in E-Commerce
}

\author{
Nia Budi Puspitasari ${ }^{1, *}$, Susatyo Nugroho $\mathrm{W} \mathrm{P}^{2}$, Deya Nilan Amyhorsea, and Aries Susanty ${ }^{4}$ \\ 1,2,3,4 Department of Industrial Engineering, Faculty of Engineering, Diponegoro University, Semarang - Indonesia
}

\begin{abstract}
The e-commerce growth and development in Indonesia is very rapid as well as the internet grows, but it is not well-balanced with the number of online buying transaction which is still relatively low. Even the today's biggest B2C e-commerce people in Indonesia, Lazada, has continually decreased online purchasing. This research is aimed to describe factors affecting online buying decision- making in the ecommerce Lazada. The type of this research is confirmatory research. The variable used is following conceptual model i.e. Electronic Word of Mouth (EWOM), social identity, risk perception, trust, and purchase intention. The data were obtained through the questionnaire with Likert scale 1-5. There are 104 people researching sample who meets the criteria as Lazada consumer that, at least do a transaction in recent six months. Data analyzing were done using Structural Equation Modelling (SEM) method by Analysis of Moment Structures (AMOS) software. The results showed that the purchase intention has positively related to the purchase decision. Variable EWOM toward trust has positive relation, variable social identity and risk perception have no any significant relation to trust. Variable risk perception toward purchase intention has no significant relation, while the variable trust has significant positive relation to purchase intention.
\end{abstract}

\section{Introduction}

Internet as a cutting-edge information technology developed that now its use has penetrated into all sectors of life, could not be separated from people nowadays lifestyle. One of those opportunities that take advantage of internet technology is in the business sector, by using electronic commerce (e-commerce)as a trading medium which everyone can access anywhere anytime.

In Indonesia, the growth and development of ecommerce are the second largest in the world in the last four years based on SparksLabs, one of the global research company. The result of the research showed the growth in 2012 by $85 \%, 2013$ by $71 \%, 2014$ by $45 \%$, and 2015 by $37 \%$, while the each forecast for 2016 and 2017 is by $26 \%$ and $22 \%[1,2]$. Can be said that the growth of e-commerce in Indonesia is experiencing rapid growth. According to the Communication and Information Ministry of Republic of Indonesia (KEMKOMINFO), the growth in 2015 is driven by Internet users continues to grow as well. At 2015, Indonesian internet users reached 93,4 million that is increased compared with 2014 which is 88,1 million users. Around $77 \%$ of internet users searched product information and online shopped with the most popular products are clothes, shoes, bags, and phones [3].

Despite the growth and development of e-commerce always increased each year, but the conducted survey by Spire Research \& Consulting in 2007-2012 stated that in Indonesia the online transaction value of e-commerce is still low if it is compared with the total value of the online and offline transaction. The percentage of online transaction in consecutive years 2007-2012 was recorded at $1,19 \% ; 1,27 \%, 1,42 \% ; 1,51 \% ; 1,79 \%$ and $2,25 \%$ [4]. It can be said of that discovery that Indonesian online shopping transaction is still relatively low.

It is also supported by the comparative value of online transaction value data of Indonesia with other south east Asian country in 2014 which is taken from Euromonitor in [5]. Based on those data, the carrying value of transaction in Indonesia was recorded at USD 1.1 billion, which only $0.7 \%$ of the total value of retail trade in Indonesia. In South East Asian, Indonesian ecommerce transaction is still inferior to the other three countries namely Malaysia, Thailand, and Singapore with each percentage at $0.9 \%, 1.2 \%$, and $3.4 \%$.

E-commerce is an online business activity both in product offerings and services, and all business transactions that involve the interaction of various parties occurs electronically and not in direct contact [6]. According Waghmare in [7] the types of e-commerce are b2b (business to business), b2c (business to consumer), c2c (consumer to consumer) and others such as the $\mathrm{g} 2 \mathrm{~g}$ (government to government).The most developed type in Indonesia is type b2c [8].

Based on the five major b2c e-commerce traffic data in Indonesia, namely Lazada, Zalora, Bhinneka, Elevania, and Blibli in the period September 2015September 2016; this period Lazada always ranked first compared with other e-commerce competitors. At the end of 2015, Lazada had a significant increase, although it was decreasing in early 2016 until mid-2016. Lazada which always occupied the first rank proves that Lazada is the biggest b2c e-commerce people today. Besides, in Alexa.com, a website visitor counter site, stated that in September 2016 Lazada was ranked out of the whole

Corresponding author: niabudipuspitasari@gmail.com 
website in Indonesia and placed itself on the first rank in category e-commerce website.

Based on the official website, Lazada Indonesia is part of Lazada Group operates in a number of countries in Southeast Asia, namely Indonesia, Malaysia, Philippines, Singapore, Thailand, and Vietnam. While the center of Lazada Group is in the Middle East, the Dubai, United Arab Emirates. The products were offered in the hundreds of thousands that are available for various categories, health and beauty, household appliances, mobile phones and tablets, electronics, and household appliances. The range of products are available from international brands to local brands. Completeness of the products offered have become one of the advantages of Lazada. The company gives consumers a chance to buy all kinds of products simply by accessing to the website that has been provided, then the product orders will be delivered to the homes of consumers with the courier services provided. Payment of the purchase transactions can be made either by cash or credit card.

Based on the theory of human behavior in the use of technology that is Theory Acceptance Model (TAM), which is the development of the Theory of Planned Behavior (TPB) has the assumption that a behavior of humans is preceded by intention or interest that is needed to be done or not to be done the behavior [9]. Thus, purchase intention and purchase actual decision have a proportional relationship.

The high interest of online shopping on e-commerce site can be seen on traffic data or traffic data web [10]. Based on traffic data, Lazada's decreasing traffic occurred in the early 2016 until mid-2016. This decrease is proportional with the online purchasing intention and purchase; thus it can be concluded that online purchasing intention and purchase also decreased. Online buying decision is affected by EWOM factors, social identity, risk perception, and trust [11].

\section{Literary Reviews}

\subsection{Technology Acceptance Model (TAM)}

Technology Acceptance Model (TAM) is one of the theories on the use of information technology systems that can be used to describe the individual acceptance of the use of information technology system. This influential theory was first introduced by Davis (1989), it is the development of Theory of Reasoned Action(TRA) by Ajzen and Fishbein (1975) in[9].

\subsection{Purchase Decision}

Consumer behavior will determine the decision-making process in their purchases. The decision-making process is a problem-solving approach that consists of five stages: problem recognition, information search, evaluation of alternatives, purchase decision and postpurchase behavior [12].

\subsection{Purchase Intention}

Purchase intention is a mental activity that precedes the act of a person before taking action using the product or service [13].

\subsection{Electronic Word of Mouth (EWOM)}

According to [14] Word of Mouth (WOM) can be described as an consumers' interpersonal communication about products or services, and in general now WOM plays a key role in influencing consumer attitudes, consumer trends and consumer behavior. WOM in this online system was called EWOM.

\subsection{Social Identity}

Identification with a social group is a psychological state that is very different from a specified social category and has important self-evaluative result. Overall, social identity can support when in a depressed state [15]. The reason why consumers actively participate in the online community is found by Dholakia et al (2004). She found that social identity motivates participation in online interaction through increased "we-intention", for example, is the commitment of the community participating in the joint action, and includes an agreement between the participants to engage in collective action. They added membership, frequency and level of participation that are driven by the will of choice [16].

\subsection{Perceived Risk}

According to Murphy and Enis (1986), quoted by [17] perception of risk is an unpredictable phenomenon encountered by consumers during the purchase process error caused by the consumer or the result of decisions that do not fit on the subjective assessment in the decision-making process. On consumer behavior and marketing literature, the perception of risk is an important concept and the various risks that have been identified [14].

\subsection{Trust}

[18] defined trust as the tendency of one party to a willingness to accept the attitude of the other party even though the first party is not protected by the second and failed to control the attitude of second parties.

\section{Method}

\subsection{Research Model}

Conceptual Research Model can be seen in Fig 1. 


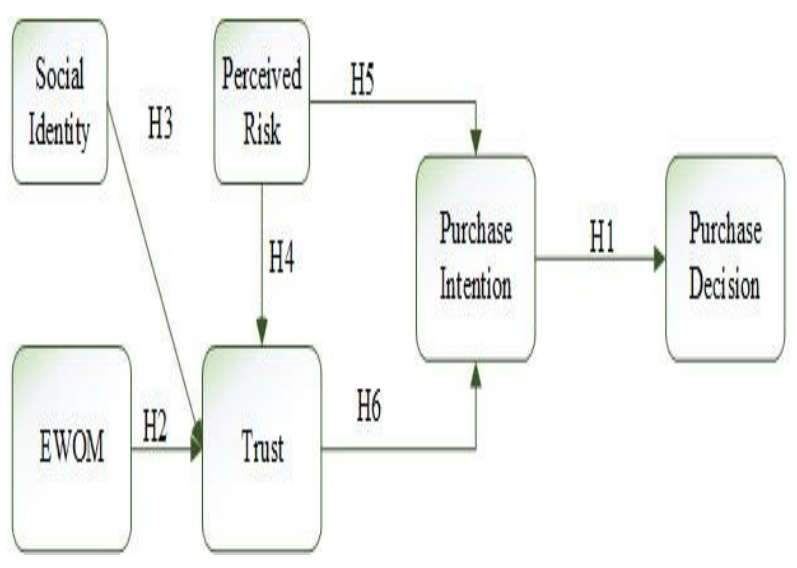

Fig. 1. Conceptual Research Model

Based on the conceptual model proposed by [11], the hypotheses will be arranged as follows:

- Hypothesis 1: Online consumer purchase intention has a positive relationship toward an actual purchase decision.

- Hypothesis 2: Electronic Word of Mouth(EWOM) has a positive relationship toward trust on ecommerce.

- Hypothesis 3: Social identity has a positive relationship toward trust on e-commerce.

- Hypothesis 4: Risk perception has a negative relationship toward trust on e-commerce.

- Hypothesis 5: Risk perception has a negative relationship toward online purchase intention on ecommerce.

- Hypothesis 6: Consumer trust has a positive relationship toward online purchase intention.

\subsection{Respondent}

This research was conducted in September 2016 using a questionnaire with Likert scale 1-5 (strongly disagree to strongly agree). The population in this research is Semarang people who within the last six months have been purchasing transaction on e-commerce Lazada. The determination of the number of samples for SEM method is based on [19], the sample size, which is recommended and generally accepted to obtain appropriate results is by using Maximum Likelihood numbered 100-200 people. Therefore, the number of samples taken in this research is 100 people and the respondents in this research are 104 people. Then, sampling technique that had been done in this research is non-probability sampling or in another word a nonrandom sampling. Nonrandom sampling or nonprobability sampling give no any similar chance for each individual in the population to be chosen as samples [20].

\subsection{Study Design}

Research indicator for each six variables are can be seen in Table 1.
Table 1. Indicator for Each Variables

\begin{tabular}{|c|c|c|c|}
\hline Construct & Variable & Indicator & Reference \\
\hline \multirow{3}{*}{ Purchase } & $\mathrm{X} 1$ & $\begin{array}{l}\text { Amount of } \\
\text { Information Search }\end{array}$ & \multirow{3}{*}{ [21] } \\
\hline & $\mathrm{X} 2$ & Consideration Set & \\
\hline & $\mathrm{X} 3$ & Purchase Decision & \\
\hline \multirow{3}{*}{$\begin{array}{l}\text { Purchase } \\
\text { Intention }\end{array}$} & $\mathrm{X} 4$ & $\begin{array}{l}\text { Transactional } \\
\text { Intention }\end{array}$ & \multirow{3}{*}[22]{} \\
\hline & $\mathrm{X5}$ & $\begin{array}{l}\text { Preferential } \\
\text { Intention }\end{array}$ & \\
\hline & $\mathrm{X} 6$ & $\begin{array}{l}\text { Explorative } \\
\text { Intention }\end{array}$ & \\
\hline \multirow{3}{*}{ Trust } & $\mathrm{X} 7$ & Trustee's Ability & \multirow{3}{*}{ [14] } \\
\hline & $\mathrm{X} 8$ & $\begin{array}{l}\text { Trustee's } \\
\text { Benevolence }\end{array}$ & \\
\hline & $\mathrm{X9}$ & Trustee's Integrity & \\
\hline \multirow{3}{*}{$\begin{array}{l}\text { Perceived } \\
\text { Risk }\end{array}$} & $\mathrm{X} 10$ & Financial Risk & \multirow{3}{*}{ [14] } \\
\hline & $\mathrm{X} 11$ & Privacy Risk & \\
\hline & $\mathrm{X} 12$ & Product Risk & \\
\hline \multirow[t]{3}{*}{$\begin{array}{l}\text { Social } \\
\text { Identity }\end{array}$} & $\mathrm{X} 13$ & $\begin{array}{l}\text { Cognitive (have a } \\
\text { community or } \\
\text { group of social } \\
\text { network sites/social } \\
\text { media) }\end{array}$ & \multirow[t]{3}{*}{ [14] } \\
\hline & $\mathrm{X} 14$ & Affective & \\
\hline & $\mathrm{X} 15$ & Evaluative & \\
\hline \multirow{4}{*}{$\begin{array}{l}\text { Electronic } \\
\text { Word of } \\
\text { Mouth } \\
\text { (EWOM) }\end{array}$} & $\mathrm{X} 16$ & EWOM Intensity & \multirow{4}{*}[23]{} \\
\hline & $\mathrm{X} 17$ & $\begin{array}{l}\text { Positive Valence } \\
\text { EWOM }\end{array}$ & \\
\hline & $\mathrm{X} 18$ & $\begin{array}{l}\text { Negative Valence } \\
\text { EWOM }\end{array}$ & \\
\hline & $\mathrm{X} 19$ & EWOM Content & \\
\hline
\end{tabular}

\section{Results}

Data analyzing was performed by using software SPSS 22.00 to test the reliability and validity of the questionnaire and AMOS 22.00 to calculate using SEM.

\subsection{Tests of Validity and Reliability of Questionnaire}

A result of SPSS output validity test states that all indicators are valid, because it has met the requirements that $r$ count is bigger than $r$ tabulated. The number of $r$ table 0,1466 is obtained from table of critical value (r) product moment with degrees of freedom $(\mathrm{N}-2)$, i.e. 125 and $p$-value 0.05 . Meanwhile, obtained reliability test states that all variables can be said reliably because had met the requirements of cronbach's alphabigger than 0,6.

\subsection{Structural Equation Modelling(SEM)}

There are 6 variables and 19 indicators which are used in this research. However, in the SEM analyzing the $18^{\text {th }}$ indicators must be dropped because it does not meet criteria on Confirmatory Factor Analysis (CFA) step. Obtained result of data analyzing could be seen in figure 2. 


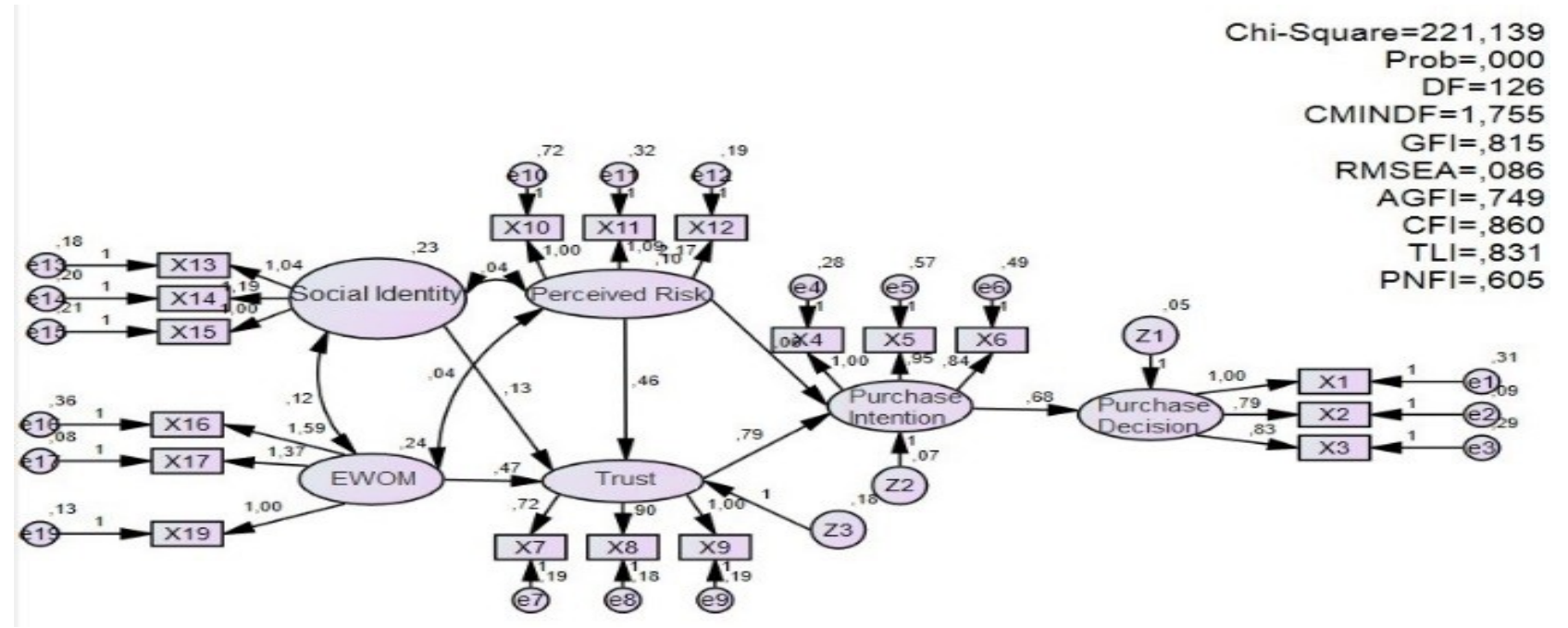

Fig. 2.AMOS Output

Table 3. AssumptionAVE Test

Based on AMOS output results, goodness of fit test can be said a good model. According to Ghozali, a model can be said good if two or more goodness of fit shows a good model fit [19] Goodness of fit test that are included in good fit are CMINDF and PNFI, it is by fullfilling required CMINDF value less than 2 and PNFI value more than 0.60.Meanwhile, another goodness of fit test shows fit index value with marginal and poor fit criteria still acceptable because the value is between 0 until 1, which is still acceptable.

Meanwhile, SEM assumption that must be fulfilled are normality, reliability test, and validity test. In normality, 23 data must be removed and only 104 data that met this assumption. Reliability and validity testing, all variables are valid $(>0,700)$ and reliable $(>0,500)$. Result of reliability test can be seen in table 2 , while the result of validity test can be seen in table 3 .

Table 2. Assumption Test Reliability

\begin{tabular}{|c|c|c|}
\hline Variable & $\begin{array}{c}\text { Sum of } \\
\text { Const } \\
\text { Reliability }\end{array}$ & Result \\
\hline Purchase & 0,660 & Good Enough Reliability \\
\hline $\begin{array}{c}\text { Purchase } \\
\text { Intention }\end{array}$ & 0,617 & Good Enough Reliability \\
\hline Trust & 0,781 & Good Reliability \\
\hline $\begin{array}{c}\text { Perceived } \\
\text { Risk }\end{array}$ & 0,603 & Good Enough Reliability \\
\hline Social Identity & 0,803 & Good Reliability \\
\hline EWOM & 0,877 & Good Reliability \\
\hline
\end{tabular}

\begin{tabular}{|c|c|c|}
\hline Variable & AVE Score & Result \\
\hline Purchase & 0,398 & Moderate \\
\hline $\begin{array}{c}\text { Purchase } \\
\text { Intention }\end{array}$ & 0,353 & Moderate \\
\hline Trust & 0,544 & Valid \\
\hline $\begin{array}{c}\text { Perceived } \\
\text { Risk }\end{array}$ & 0,365 & Moderate \\
\hline Social Identity & 0,576 & Valid \\
\hline EWOM & 0,704 & Valid \\
\hline
\end{tabular}

Then, the result of hypothesis testing using SEM can be seen in table 4 .

Table 4. Result of Hypothesis Testing

\begin{tabular}{|c|c|c|c|}
\hline Hypothesis & C.R. (>1,96) & $\begin{array}{c}\mathbf{P} \\
\mathbf{( < \mathbf { 0 , 0 5 } )}\end{array}$ & Result \\
\hline H1 & 4,464 & 0,000 & Accepted \\
\hline H2 & 3,189 & 0,001 & Accepted \\
\hline H3 & 0,849 & 0,396 & Rejected \\
\hline H4 & 1,842 & 0,065 & Rejected \\
\hline H5 & 0,271 & 0,786 & Rejected \\
\hline H6 & 4,901 & 0,000 & Accepted \\
\hline
\end{tabular}

\section{Discussions}

The comparison between this research result and previous journal are similar results for hypothesis 1, 2, 3, and 6. However, hypothesis 1,2 , and 6 stated result significantly affects whereas hypothesis 3 has no significant influence. There is a difference on hypothesis 4 and hypothesis 5 where the journal stated that the conclusion is accepted which means it has significant influence while the research result stated it has no significant influence. 
Based on obtaining results, first hypothesis regarding online consumer purchase intention have a positive relationship toward a purchase decision, it has significant influence. Therefore, research result is appropriate to previous research conducted by [11] in Iran. This research result is also supported by [14] result that stated that consumer intention in performing a behavior is an important determinant of the next actual behavior. The result of second hypothesis is also supported by research that is conducted by [24] which stated that the more distributed information quantity and EWOM actuality, the bigger consumer trust on e-commerce. The third one is third hypothesis, social identity has a positive relationship with trust on e-commerce. As a result, it has no significant influence, similar to previous research by [11]. This hypothesis is unacceptable because the questionnaire might not be directed at appropriate consumer. It is caused by almost $50 \%$ of respondents has once purchase transaction in the last six months, which can identify the increased level of distrust of obtaining answers. Besides, can be caused by members of a group or a social network community have no close relationship.

Fourth hypothesis, risk perception has negative toward trust on e-commerce. Previous research concludes it is significant, which means higher risk perception, the lower trust will be. Meanwhile, this research shows another result, non-significant influence which is contrary to a study conducted by [14]. This phenomenon can be caused by respondents who have experience in performing online purchasing transaction. In the fifth hypothesis, although theory says high risk perception will decrease purchase intention, but this research says the contrary. The reason is because of their attractive promotions such as discount price given by Lazada even the risk perception is high, their free shipping for certain products also affects the purchase interest is still high. The sixth hypothesis is supported by [17] who stated that there is a positive relationship between trust and online purchase intention. The higher the trust, the higher purchase intention will be.

Improvements recommendation performed on the most influencing variable. Based on SEM analyzing on standardized total effects, trust variable has the biggest value. Therefore, this variable is the most influencing toward purchase intention. The recommendations are it should renew website design regularly, shorten link about product guarantee and its term and condition, use logo to protect personal data and the room, regularly report Lazada'strack record, fill Lazada blog content with profile video and press release, and maximize the use of social media official Lazada.

\section{Conclusions}

Based on the analysis that has been done, it can be concluded that:

1. Online purchase intention has a significant positive influence toward an actual decision on online purchase of e-commerce Lazada.
2. Electronic Word of Mouth(EWOM) has a positive effect toward trust in e-commerce Lazada purchase transactions while social identity and risk perception do not have a significant influence toward trust on ecommerce Lazada purchase transactions.

3. Risk perception has no significant relationship toward the online purchase intention in purchasing transactions of e-commerce Lazada but the trust has a significant positive influence on online purchase intention in e-commerce Lazada purchasing transactions.

4. The factors that most significantly affect online purchase intention in e-commerce Lazada is trust, because it has the greatest results in the processing of SEM. If Lazada can give trust to consumers and they feel it is high enough in Lazada, it can push them to perform online purchasing transactions at Lazada.

5. Recommendations or suggestion given to ecommerce Lazada is by increasing the trust which are composed of three indicators, namely the ability, the track record $t$, and the integrity of party that give trust.

\section{References}

1. M. P. AlHafiz, http://marketeers.com (2016)

2. A. M. A. Maulani, http://e27.co (2016)

3. Kominfo,https://kominfo.go.id/index.php/content/d etail/6385/Potensi+Besar+untuk+Pemasukan + Neg ara/0/infografis/(2015)

4. Spireresearch, https://www.spireresearch.com/news room/media/ (2012)

5. Y Syahrul, A Daud, http://katadata.co.id/telaah/2015/12/18/indonesiapasar-e-commerce-terbesar-di-asean-denganbanyak-kendala (2015)

6. Z.R. Andam, E-Commerce and E-Business. (UNDP-APDIP, Kuala Lumpur, 2003)

7. D.K. Gangeshwer, I.J. of u- and e-Service, Science and Tech, 6(6), 187-194 (2013)

8. Clare, http://www.prnewswire.com/news-releases. (2016)

9. Fred D.Davis, R. P. Bagozzi, P. R. Warshaw. Mgt. Sc.,35, 982-1003(1989)

10. C. Andini, Claudia, M. Ariyanti, Sumrahadi. eProceeding of Management, 3 (2016)

11. M. Takhire, M. R Taghizadezh Joorshari. Int Journal of Managing Public Sector Informtand Comm Techs, 6, 3 (2015)

12. Kotler and Armstrong. Prinsip-Prinsip Pemasaran Jilid 1 Edisi Kedelapan (2001)

13. N. D. Paramita, and N. N. Kerti Yasa, JMK, 17, 2, 177-185, (2015)

14. D.J. Kim, D. L. Ferrin, dan H. R. Rao. DSS,44, 544-564 (2008)

15. D. Frings, Daniel, I. P. Albery, Addict Behav., 44, 35-42 (2015)

16. U. M. Dholakia, R. P. Bagozzi, dan L. K. Pearo, IJRM, 21, 241-263 (2004) 
17. K. C. Ling, D. bin Daud, T. H. Piew, K. H. Keoy, P. Hassan, IJBM, 6,167-182 (2011)

18. R. C. Mayer, J. H. Davis, dan F. D.Schoorman, Acad. Of Manag. Rev., 10,709-734. (1995)

19. I. Ghozali, Structural Equation Modelling Teori, Konsep dan Aplikasi (Badan Penerbit Universitas Diponegoro, 2008)

20. Sugiyono. Metode Penelitian Pendidikan (Alfabeta, 2011)
21. G. Haubl, V. Trifts. MKSC, 19, 4-21 (2000)

22. R. D. Agustin, S. Kumadji, E. Yulianto, J Adm Bis UB, 22, 1-10 (2015)

23. I. Goyette, L. Richard, J. Bergeron, F. Marticotte, Can J Adm Sci, 27, 5-23 (2010)

24. F. Xiaorong, Z. Bin, X. Qinghong, X. Liuli, C Yu, AJBR, 1, 37-52 (2011) 